\title{
Gender as a Predictor in Adolescents' Television Use
}

\author{
Smitha $\mathrm{P}^{1}$, Dr.Muhammadali $\mathrm{N}^{2}$ \\ 1(Research Fellow, Department of Journalism \& Mass Communication, University of Calicut, Kerala, India) \\ 2(Assistant Professor, Department of Journalism \& Mass Communication, University of Calicut, Kerala, India)
}

\begin{abstract}
Television has become an inseparable part of our lives. Television has a strong impact on all individuals, especially adolescents as they are vulnerable to change. The present study tries to find out the relationship between the gender and adolescents' television use. A survey was employed among 540 (270male and 270 female) students from different schools in Kerala. The Study revealed that male students and female students are using television differently and their selection of the program also varies. Male students spent more time with television than female students.
\end{abstract}

Keywords - Gender, Television, Media, Usage, Adolescents, Programs

\section{INTRODUCTION}

Technology is advancing at an ever increasing rate that our media consumption is also on the rise. The youth are certainly at the forefront to adapt and consume the technological advancements. They take on a huge quantum of information and knowledge from the media. Since every individual depends on some kind of media for information; it is the best means to bring awareness in the society. Even though the internet and new media are changing at a rapid pace, TV is yet a required factor in daily lives of people. It is one of the most influential medium. It has an important role to play for entertainment and educational resources as well. As, the television does, in fact, serves an educational purpose it is significant to explore how it meant for the adolescents. In this background the present study is focusing on the adolescents' television use, program selection and how it is related to gender.

\subsection{Television and adolescents}

Television plays a vital role in today's society with several impacts on people of all age groups especially adolescents. A number of researches were conducted to retrieve out the impact of television on teenagers, to explore both positive and negative effects. Adolescents are spending a huge portion of their time in viewing television more. American youngsters, between ages 2-17, watch television on an average of $3 \frac{1}{2}$ hours per day. Nearly one in five watch TV more than 35 hours per week (Gentle and Walsh, 2002, Ozdmir 2006).TV can influence viewers' attitude and behavior.TV viewing of middle class Indian youth is typically a relaxed cure to the stresses of the day that they share with their families and it can influence the adolescent's life (Verma and Larson 2002). Television viewing, boon or a bane is an on going argument. Considerably, it has both positive and negative sides. Moderate viewing was found to beneficial for reading, and that the program content viewed by children matters (Moses 2008). It has negative effects as well.TV viewing is linked to more behavior outcome and poor school performance among children and teenagers ( Bankston 1999, chtistakis et al. 2004 van ivra 2004 johnson et al 2004). Higher viewing leads to attention problem and hyperactivity among preschool children (miller 2007).

\section{I.2. Gender and media use}

Today we are dwelling in a universe overshadowed by media. It has become an inevitable part of our day to day activities. Youth are becoming highly influenced from the media. There are instances revealing that like the age groups, gender difference also has some relationships with media use. In television viewing, boys spend more time than girls (gentle et al 2004, Marshall et al 2006,). The program content preference seems to be different for boys and girls. The male students (between ages 7-17) like to watch fights, action, comedy and horror films and the female students like to watch comedy, horror films and TV series. Mostly they look upon a character and want to play like their famous character (ozdemir2006). Males are watching television more purposefully and they are goal-directed in their viewing and they have already planned what they will watch (Morley, 1986, 1988). Females are watching TV as a social context to pass time with others because it is a secondary activity around which interpersonal or emotional goals are required (Morley, 1988). Males had an active viewing style, with goal-directed reasons for looking out and intently, concentrated, and selective 
utilization of television. Females had a relationship-oriented approach to television similar to the expressive orientation (Amy et al 1997).

\subsection{Adolescents' gender and television use}

Nowadays adolescents are engaging most of their free time in consuming different types of media. US department of education (2002) found that young people watch television almost three hours per day. Television programs, especially types of programs have an important role in adolescent behaviour. Male adolescents prefer to watch action movies more than any other types of movies (Nazari et al 2013). In another study the male students between 7-17 ages like to watch fights, action, and comedy and horror film and the female students like to watch comedy, horror films and TV series (Ozdemir2006).

\section{REVIEW OF LITERATURE}

Verma and Larson (2002) examined the daily context and experience of TV viewing for middle class Indian adolescents. It found that the television viewing of middle class Indian youth is typically a relaxed cure to the stresses of the day that they share with their families.

Sarem ozdemir (2006) investigates the effect of television on children and adolescents. It found that Children and adolescents are spending the majority of their time with television. The male students ages of 7-17 like to watch fights, action, and comedy and horror film and the female students like to watch comedy, horror films and Tv series. Mostly they esteem a character and want to act like their famous character. The low percentage of the Children likes to watch educational program because programs are not broadcasted in the prime time. Overall the study concludes that television viewing is a very popular activity that all people participate and viewers can learn anything that is violence, love etc. from depictions of the television channel

Landhuis et al. (2007) attempt to analyse television viewing and attention problems in adolescents. The study found there is a significant correlation between childhood and adolescent's television viewing. The Early attention problem and adolescent's attention problems were correlated. The study concludes with excessive television viewing may lead to children and adolescence attention problems.

Syed Noor-Ul-Amin (2013) attempt to find out heavy and low viewers of television and compare the academic achievement on the basis of their socio- economic status. The Study revealed that low television viewer adolescents perform scholarly than a heavy television viewer group of adolescents. It also revealed that there was no significant difference in academic achievement on the basis of gender.

Nazari et al (2013) attempts to analyze the relationship between television program genre and aggressive behaviour in primary school students. The Results indicate that there are a significant relation between television program genre and aggressive behaviour of children. Children coded their favorite program order like Action, adventure, Action, Sport and Horror. Another finding of the study was male adolescents more prefer to watch action movies than any other types of movie..

\section{OBJECTIVES}

To identify the heavy and low television viewers

To find out how level of use, type of programs, etc. are related to gender

\section{HYPOTHESIS}

H1: gender and level of television usage are significantly related

H2: gender and type of television programs are significantly associated

V. METHODOLOGY

High school students in Kerala constituted the population of the study. Researcher adopted survey method and questionnaire was used as the tool.

\section{V.1 Sample}

The survey was conducted among students from different schools in Kerala. The researcher gathered and analyzed 540 (270 male \& 270 females) responses of students from different schools in Kerala. 
Gender as a predictor in adolescents' television use

VI. ANALYSIS

Table 1. Gender and Television Usage

\begin{tabular}{|l|l|l|l|}
\hline \multirow{2}{*}{ Usage } & \multicolumn{2}{|l|}{ Gender } & \multirow{2}{*}{ Total } \\
\cline { 2 - 3 } & Male & Female & \\
\hline Low & $142(46.71 \%)$ & $162(53.28 \%)$ & $304(100)$ \\
\hline Medium & $63(47.01 \%)$ & $71(52.98 \%)$ & $134(100)$ \\
\hline High & $65(63.72 \%)$ & $37(36.27 \%)$ & $102(100)$ \\
\hline
\end{tabular}

Pearson Chi-Square $=9.480, d f=2, P$ value $=0.009$

With respect to level of television usage Majority of the respondents are low users. However, among high users, male students $(63.72 \%)$ spend more time than female $(36.270 \%)$. Male students seem to have the tendency to spend more time with television. There is a significant relation between gender and the level of television usage ( $\mathrm{p}$ value $=0.009)$.

Table 2. Gender and News Programs

\begin{tabular}{|l|l|l|l|}
\hline \multirow{2}{*}{ News programs } & \multicolumn{2}{|l|}{ Gender } & \multirow{2}{*}{ Total } \\
\cline { 2 - 3 } & Male & Female & \\
\hline Always & $51(57.30 \%)$ & $38(42.69 \%)$ & $89(16.48 \%)$ \\
\hline Sometimes & $201(49.02 \%)$ & $209(50.97 \%)$ & $410(75.92 \%)$ \\
\hline Never & $18(43.90 \%)$ & $23(56.09 \%)$ & $41(7.59 \%)$ \\
\hline
\end{tabular}

Pearson Chi-Square $=2.665, d f=2, P$ value $=.264$

Among the total respondents Majority $(75.92 \%)$ of the students watch news programs 'sometimes'. $49.02 \%$ of male students and $50.97 \%$ of female students belong to this category. Simple minority (7.59\%) of the students never watch news programs. The table shows that there is no statistically significant relation ( $p$ value $=0.264$ ) between news programs and gender.

Table 3. Gender and News based serious Programs

\begin{tabular}{|c|c|c|c|}
\hline \multirow{2}{*}{$\begin{array}{l}\text { News based serious } \\
\text { programs }\end{array}$} & \multicolumn{2}{|c|}{ Gender } & \multirow{2}{*}{ Total } \\
\hline & Male & Female & \\
\hline Always & $29(65.90 \%)$ & $15(34.09 \%)$ & $44(8.14 \%)$ \\
\hline Sometimes & $148(47.28 \%)$ & $165(52.71 \%)$ & $313(57.96 \%)$ \\
\hline Never & $93(50.81 \%)$ & $90(49.18 \%)$ & $183(33.88 \%)$ \\
\hline
\end{tabular}

Pearson Chi-Square $=5.427, d f=2, P$ value $=.066$

Among the total respondents majority $(57.96 \%)$ of the students watch news based serious programs at least sometimes. $47.28 \%$ of male students and $52.71 \%$ of female students belong to this category. On the other hand simple minority $(8.14 \%)$ of the students always watch this type of programs. The table shows that gender and news based serious programs are not related. The difference is not statistically significant ( $\mathrm{p}$ value $=.066$ ).

Table 4. Gender and News based Comedy Programs

\begin{tabular}{|l|l|l|l|}
\hline \multirow{2}{*}{$\begin{array}{l}\text { News based comedy } \\
\text { programs }\end{array}$} & Gender & \multirow{2}{*}{ Total } \\
\cline { 2 - 3 } & Male & Female & \\
\hline Always & $42(56.75 \%)$ & $32(43.24 \%)$ & $74(13.70 \%)$ \\
\hline Sometimes & $158(51.63 \%)$ & $148(48.36 \%)$ & $306(56.66 \%)$ \\
\hline Never & $70(43.75 \%)$ & $90(56.25 \%)$ & $160(29.62 \%)$ \\
\hline
\end{tabular}

Pearson Chi-Square $=4.178, d f=2, P$ value $=.124$

Among the total respondents, majority (56.66\%) of the students watch news based comedy programs at least sometimes. At the same time simple minority $(29.62 \%)$ of the students never watch these types of programs. The table shows that the relation between gender and news based comedy programs is not significant. The $\mathrm{p}$ value $=(.124)$. 
Table 5. Gender and Educational Programs

\begin{tabular}{|l|l|l|l|}
\hline \multirow{2}{*}{ Educational programs } & \multicolumn{2}{|l|}{ Gender } & \multirow{2}{*}{ Total } \\
\cline { 2 - 3 } & Male & Female & \\
\hline Always & $60(50 \%)$ & $60(50 \%)$ & $120(22.22 \%)$ \\
\hline Sometimes & $184(49.46 \%)$ & $188(50.53 \%)$ & $372(68.88 \%)$ \\
\hline Never & $26(54.16 \%)$ & $22(45.83 \%)$ & $48(8.88 \%)$ \\
\hline
\end{tabular}

Pearson Chi-Square $=.376, d f=2, P$ value $=.828$

The majority $(68.88 \%)$ of the students watch educational programs at least sometimes. On the other hand simple minority $(8.88 \%)$ of the students never watch educational programs. The table shows that majority of both the groups of students watch educational programs. Also, it shows that there is no relationship between gender and educational programs. The difference is statistically not significant $\mathrm{p}$ value $=(.828)$

Table 6. Gender and Documentaries/Travelogue/Cookery Shows

\begin{tabular}{|l|l|l|l|}
\hline \multirow{2}{*}{$\begin{array}{c}\text { Documentaries/travelogue/cookery } \\
\text { shows etc. }\end{array}$} & \multicolumn{2}{|c|}{ Gender } & \multirow{2}{*}{ Total } \\
\cline { 2 - 3 } & Male & Female & \\
\hline Always & $57(42.53 \%)$ & $77(57.46 \%)$ & $134(24.81 \%)$ \\
\hline Sometimes & $151(48.70 \%)$ & $159(51.29 \%)$ & $310(57.40 \%)$ \\
\hline Never & $62(64.58 \%)$ & $34(35.41 \%)$ & $96(17.77 \%)$ \\
\hline
\end{tabular}

Pearson Chi-Square $=11.358, d f=2, P$ value $=.003$

Among the total respondents, the majority (57.40\%) of the students watch documentary, travelogue, cookery shows etc. at least sometimes. $48.70 \%$ of the male students and the $51.29 \%$ of the female students belong to this category. The table shows female students spend more time to watch this type of programs than their male counterparts. $\mathrm{p}$ value (.003) shows there is a significant relation between gender and documentary, travelogue, cookery show programs

Table 7. Gender and Edutainment Programs

\begin{tabular}{|l|l|l|l|}
\hline \multirow{2}{*}{ Edutainment programs } & \multicolumn{2}{|l|}{ Gender } & \multirow{2}{*}{ Total } \\
\cline { 2 - 3 } & Male & Female & \\
\hline Always & $82(53.94 \%)$ & $70(46.05 \%)$ & $152(28.14 \%)$ \\
\hline Sometimes & $153(50.32 \%)$ & $151(49.67 \%)$ & $304(56.29 \%)$ \\
\hline Never & $35(41.66 \%)$ & $49(58.33 \%)$ & $84(15.55 \%)$ \\
\hline
\end{tabular}

Pearson Chi-Square $=3.294, d f=2, P$ value $=.193$

The majority (56.29\%) of the students sometimes watch edutainment programs. a minority (15.55\%) of the students never watch this type of programs.41.66\% of the male students and $58.33 \%$ of the female students belong to this category. The table shows that both the groups seem to be tending to watch this type of programs. And there is no relationship between gender and edutainment programs. The difference is not statistically significant $\mathrm{p}$ value $=(.193)$

Table 8. Gender and Entertainment programs (Film/Serial/Comedy)

\begin{tabular}{|l|l|l|l|}
\hline \multirow{2}{*}{$\begin{array}{l}\text { Film, serial and comedy } \\
\text { programs }\end{array}$} & \multicolumn{2}{|l|}{ Gender } & \multirow{2}{*}{ Total } \\
\cline { 2 - 3 } & Male & Female & \\
\hline Always & $200(54.20 \%)$ & $169(45.79 \%)$ & $369(68.33 \%)$ \\
\hline Sometimes & $63(39.87 \%)$ & $95(60.12 \%)$ & $158(29.25 \%)$ \\
\hline Never & $7(53.84 \%)$ & $6(46.15 \%)$ & $13(2.40 \%)$ \\
\hline
\end{tabular}

Pearson Chi-Square $=9.162, d f=2, P$ value $=.010$ 
The Majority $(68.33 \%)$ of the students always watch film, Serial, and comedy programs. $54.20 \%$ of the male students and $45.79 \%$ of the female students belong to this category. On the other hand simple minority $(2.40 \%)$ of the students never watch this type of programs. the table shows that male students watch these programs than their female counterparts. And it shows that there is a significant relationship between gender and these programs. The difference is statistically significant $\mathrm{p}$ value $=(.010)$

Table 9. Gender and Sports

\begin{tabular}{|l|l|l|l|}
\hline \multirow{2}{*}{ Sports } & Gender & \multirow{2}{*}{ Total } \\
\cline { 2 - 4 } & Male & Female & \\
\hline Always & $183(79.22 \%)$ & $48(20.77 \%)$ & $231(42.77 \%)$ \\
\hline Sometimes & $80(35.55 \%)$ & $145(64.44 \%)$ & $225(41.66 \%)$ \\
\hline Never & $7(8.33 \%)$ & $77(91.66 \%)$ & $84(15.55 \%)$ \\
\hline
\end{tabular}

Pearson Chi-Square $=1.560, d f=2, P$ value $=.000$

Among the total respondents majority $(42.77 \%)$ of the students regularly watch sports programs. $79.22 \%$ of the male students and $20.77 \%$ of the female students belong to this category. Male students spend more time to watch sports programs than female students. On the other hand majority (91.66\%) of the female students never watch sports programs. The table shows that gender and sports programs are related. The difference is statistically highly significant ( $\mathrm{p}$ value $=0.000$ ).

Table 10. Gender and Cartoons

\begin{tabular}{|l|l|l|l|}
\hline \multirow{2}{*}{ Cartoons } & Gender & \multirow{2}{*}{ Total } \\
\cline { 2 - 3 } & Male & Female & \\
\hline Always & $67(50.75 \%)$ & $65(49.24 \%)$ & $132(24.44 \%)$ \\
\hline Sometimes & $120(46.87 \%)$ & $136(53.12 \%)$ & $256(47.40 \%)$ \\
\hline Never & $83(54.60 \%)$ & $69(45.39 \%)$ & $152(28.14 \%)$ \\
\hline
\end{tabular}

Pearson Chi-Square $=2.320, d f=2$, P value $=.314$

Among the total respondents Majority $(47.40 \%)$ of the students watch cartoons at least sometimes. $46.87 \%$ of the male students and $53.12 \%$ of the female students belong to this category. At the same time, simple minority $(28.14 \%)$ of the students never watch cartoons. The table shows there is no gender difference in watching cartoon programs. The difference is statistically not significant $\mathrm{p}$ value $=(.314)$

Table 11. Gender and Other Programs

\begin{tabular}{|l|l|l|l|}
\hline \multirow{2}{*}{ Other programs } & \multicolumn{2}{|l|}{ Gender } & \multirow{2}{*}{ Total } \\
\cline { 2 - 3 } & Male & Female & \\
\hline Always & $53(41.73 \%)$ & $74(58.26 \%)$ & $128(23.70 \%)$ \\
\hline Sometimes & $120(58.25 \%)$ & $104(50.48 \%)$ & $224(41.48 \%)$ \\
\hline Never & $115(55.55 \%)$ & $92(44.44 \%)$ & $207(38.33 \%)$ \\
\hline
\end{tabular}

Pearson Chi-Square=6.047, $d f=2, P$ value $=.049$

Among the total respondents Majority (41.48\%) of the students watch other programs (song) at least sometimes.58.25\% of the male students and $50.48 \%$ of the female students belong to this category. On the other hand minority $(38.33 \%)$ of the students never watch these types of programs. The table shows that female students watch these programs than male students. And it shows that there is relationship between gender and this category of programs. The difference is statistically significant $P$ value $=(.049)$

\section{VII.}

\section{FINDINGS}

$>$ The Majority of the respondents are low television users, however, among the high viewers, male students seems to be spending more time with television than female students.

$>$ There is no gender difference in watching educational programs. Majority of both groups are watching educational programs.

$>$ Male students watch sports programs more than female students

$>$ Female students watch documentary, travelogue and cookery shows than male students

$>$ Male students spend more time with film, serials and comedy programs than female students.

$>$ Female students watch other programs like songs than male students. 


\section{VIII.}

CONCLUSION

Television has an important role to play for the education and entertainment in adolescents' daily life. It provides varied experiences to adolescents, thereby enriches their knowledge and awareness about the world. They spent most of their leisure time engaging in television viewing. The present study attempts to find out the relationship between adolescents gender and television use. Gender is a main indicator in adolescents television use. Male students seem to spend most of their time with television.

The study shows that there is a difference in preference of television program genres among adolescents. Male students like to watch programs like sports. Film etc. and the female students prefer programs like documentary, travelogue, cookery shows, etc. Both groups prefer watching educational programs.

The study has some limitations too, only gender and the television programs were analyzed and the sample selection was limited to Kerala only. It is recommended to conduct the study in a broader way that will give a clear picture on the gender and adolescents' television use.

\section{REFERENCES}

[1] Ozdemir, S. (2006). Affects of Television as a Natural Educator;can Television be a Tool as an Informal Educator? A TRNC Sample. Turkish Online Journal of Educational Technology, 5 (1), 3-13.

[2] Verma, S. \& Larson, R.W. (2002). Television in Indian Adolescent's Lives; A Member of the Family. Journal of Youth and Adolescence, 31 (3), 177-183.www.springer.com

[3] Nathanson, A. I., Perse, E. M., \&Ferguson, D. A. (1997). gender differences in television use : an exploration of the instrumental -expressive dichotomy. communication research reports, 14 (2), 176-188.

[4] Gentile, D.A., Lynch, P.J., Linder, J.R., and Walsh, D.A.,( 2004) The effects of violent video game habits on adolescent hostility, aggressive behaviors, and school performance. Journal of Adolescence.27 $5-22$.

[5] Marshall, S.J., Gorely, T., \& Biddle, S.J .H., (2006)A descriptive epidemiology of screen-based media use in youth: A review and critique. Journal of Adolescence;29:333-349.

[6] Landhuis, C.E., Poulton, R.,Welch, D.,\& Hancox, R.J. (2007). Does Childhood Television viewing Lead to Attention Problems in Aolescence? Pediatrics, 120 (3), 532-537. htt://www.pediatrics.aappublications.org 19-4-2013

[7] Nazari,M.R., Hassan, M.H.,Ozman,M.N., Yazin,M.B.,\&Parhizkar,S(2013) Influence of Television Programs Genre on Violent Behaviour among Young ChildrenBritish Journal of Education, Society \&Behavioural Science Vol.3 No 4 pp519-531 www.Sciencedomain.org

[8] Amin, S. N.-U. (2013). Impact of Television Watching on Academic Achievement of Adolescents with Special reference to their Socio economic Status. Standard Journal of Education and Essay, 1 (1), 14-20, www.http://standresjournals.org 